\title{
KITEKINTÖ
}

\section{EURÓPAI UNIÓ: ALKOTMÁNYFEJLŐDÉS ÉS REGIONALIZMUS}

(European Union: The development of the constitution and regionalism)

\author{
SZILÁGYI ISTVÁN
}

A Maastrichti Egyezmény után politikai-jogi értelemben felgyorsult a kibővítés és az elmélyítés dilemmájával küzdő európai integráció folyamata. 1995 januárjától a "tizenkettekhez" Ausztria, Finnország és Svédország is csatlakozott. Napirenden van az Unió további bővítése (az még nem eldöntött, hogy a Mediterráneum vagy Kelet-KözépEurópa irányába) és a tagállamok közötti együttmúködés elmélyítése.

Mindez komoly szervezeti, politikai, jogi-alkotmányjogi problémákkal és konfliktusokkal jảr, s számos kérđést vet fel. Megszünik, megszüntethetö-e az Unió demokratikus deficitje? Létrejôn-e az egységes választójogi rendszer? Megszületik-e az Unió normatív alaptörvényi szabályozása, s mi lesz ennek a tartalma? Hogyan alakul a nemzeti és a szupranacionális intézmények egymáshoz való viszonya? Miképpen érvényesül a szubszidiaritás szivárványszinủ elve? Hogyan változik a döntéshozatali mechanizmus? Föderációs vagy konföderációs formában, parlamentáris vagy prezidenciális rendszerben szervezódik-e a majdani egységes Európa-ház? Hogyan alakul a regionális szabályozás és támogatás jövőbeni szisztémája, s egyáltalán: hogyan illeszkedik az európaizálódás folyamatába a regionális rendszer, az állampolgár, a (tag)államok és az európai intézmények hálójában elhelyezkedö "közvetítỏ kormányzat"? $\$$ végül: mindezek milyen hatást gyakorolnak, gyakorolhatnak Magyarország Európai Unióhoz, való csatlakozására, a magyar regionális rendszer fejlödésére és az alkotmányozási folyamatra.

\section{Demokratikus deficit és európai alkotmány}

1996 közepére már nyilvánvalóvá vált, hogy a Maastrichti Egyezményben megfogalmazott gazdasági és szociális összefogás erősítése, a hosszú távon egységes valutát is magában foglaló gazdasági, pénzügyi uniớ és bankrendszer időarányos kialakításának menetrendje nem tartható. Gondok vannak a közös kül- és biztonságpolitikával, és az oly hơn áhított unió állampolgárság státuszának kialakításával, tartalmi meghatározásával is. Indokolt tehát a Maastrichti Egyezmény elóírásainak megfelelóen az 1996-os torinói kormányközi konferencia összehívása, az eddig megtett út áttekintése és a helyzetfelmérés.

Az, hogy egy nemzetközi egyezmény nem minden pontját, elöírását tudják, képesek maradéktalanul megvalósítani, betartani a szerződő felek, nem számít nagy újdonságnak a nemzetkőzi politikában és a nemzetközi jogban. Ebből a szempontból az Európai Uniót 
létrehozó történelmi jelentőségü Maastrichti Szerződés sem tekinthetö kivételnek. A hosszú távú makrofolyamatok és tendenciák sorsa nem néhány dátumszerüen rögzített esemény bekövetkezésének átmeneti késlekedésén múlik. Azon viszont igen, hogy megvan-e, fennáll-e a Magas Szerződö Felek politikai akarata az egyezmény végrehajtására, avagy merik-e vállalni a sorsdöntó lépések társadalmi, s még inkább történelmi kockázatát. Az európai "tizenötök" ezzel a dilemmával néznek szembe, s az oly sokszor és szivesen hangoztatott demokratikus deficit kifejezés ennek a helyzetnek, ennek az állapotnak a megjelölésére szolgál (Boyce, B. 1993, Izikné Hedri G. 1994).

$\mathrm{Az}$ Európai Unió demokratikus deficitje kifejezés tartalmilag mindenekelőtt egy, az európai parlamenti képviselöi helyek betöltésére szolgáló egységes választójogi rendszer hiányát jelenti. Jelenti továbbá e választások másodlagos jellegét, a nemzeti megmérettetésekhez képest. Annak ellenére így van ez, hogy az Európai Unió országainak állampolgárai szavazataikkal közvetlenül, alakító módon befolyásolják, meghatározzák a supranacionális képviselótestület (pártbeli) összetételét. Elvileg tehát a demokratikus legitimáció legfontosabb kellékei, kritériumai jelen vannak a nemzeti keretekben megvalósuló európai parlamenti választásokon.

Az Európai Unió demokratikus deficitje megnyilvánul szervezeteinek müködésében, a választott és a kinevezett, vagy delegált küldöttekböl álló testületek közötti hatásköri tisztázatlanságban, átfedésekben, a hatalommegosztás klasszikus és demokratikus elveinek, technikáinak, eljárásmódjának keveredésében.

A közösség demokratikus adósságai közé tartozik végezetül egy, a tagállamok egybehangzó politikai akaratát jogi formában is megjelenítỏ európai alkotmány elfogadása. Milyen legyen ez az alaptörvény? Mire terjedjen ki kompetenciája, milyen politikai berendezkedést intézményesítsen? Ezek már a nemzeti szuverenitás alapjait érintő kérdések.

Az Európai Unió azonban sui generis, sem a nemzeti, sem más nemzetközi szerveződéssel össze nem vethetö politikai forma. Ezért a demokratikus deficit megszüntetésének a hagyományos megoldásoktól tartalmilag eltérö, azokkal mindössze formai hasonlóságot mutató megoldásai jöhetnek csak szóba.

Tény az, hogy már az ötvenes évek "alapító atyái" is tơrekedtek a nemzeti szuverenitás érvényesülését komolyan befolyásoló, akkoriban még Európai Közgyủlésnek nevezett szervezet egységes választójogi eljárásának kidolgozására. Ezzel kapcsolatban négy, egymással szorosan összefüggõ, s napjainkban is időszerủ kérdést kellett megválaszolniuk.

1. Az európai képviselőtestület tagjainak megbízatása általános és közvetlen választójog alapján jöjjön-e létre, vagy a nemzeti parlamentek delegálják az euro-honatyákat?

2. Egymást kizárónak tekinthetök-e a nemzeti és az euromandátumok?

3. Kialakíthatók-e a közös választójogi szabályok?

4. A létrejött Európai Parlament kompetenciái hogyan alakuljanak?

Mint jeleztük, már az Európai Szén- és Acélközösséget létrehozó 1951-es Párizsi Szerződés is a vázolt két út (nemzeti parlamentek delegálása vagy általános, közvetlen választójog) közötti választást javasolta. A gyakorlatban az első alternativa érvényesültt. Elvi szinten azonban a második változatot fogadták el. Ennek a tudathasadásos helyzetnek az ellentmondásait kísérelte meg feloldani két évvel később az ún. Teitgen-terv. A dokumentum készitői kétkamarás Európai Közgyülést javasoltak. Az elsö(alsó) ház 268 képviselője közvetlen euroválasztás alapján kerülne be a testületbe. A szenátust 87 , 
nemzeti parlamentek által delegált honatya alkotná. A tervezet ugyanakkor síkra szállt az egységes választójogi rendszer kidolgozása mellett.

Az Európai Gazdasági Közösséget és az Euratomot megteremtö 1957-es Római Egyezmény 138. § (3) is erre törekedett, s kimondta: "Az Európai Parlament javaslatokat dolgoz ki az általános, közvetlen, minden, tagállamban egységes eljárás szerint folyó választásokra.

A Tanács egyhangú határozattal meghozza a megfelelő rendelkezéseket, és a tagállamoknak - alkotmányjogi előírásaiknak megfelelően - elfogadásra ajánlja." ( $A z$ Európai Közösségek Jogszabályainak Gyüjteménye. l. Alapintézmények, 1992. 59. o.)

Az idézett paragrafus azonban szándékai ellenére sem mondta ki az utolsó szót ez ügyben. A nemzeti szuverenitást jelentős mértékben korlátozó rendelkezés látszólag egységes elfogadása ellenére tovább folytatódott a tagországok tétovázása. Az Európai Gazdasági Közösség, majd az Európai Unió periódusában ${ }^{1}$ újabb tervezetek sora kísérelte meg a egységes választójogi rendszer kialakítását. ${ }^{2} \mathrm{Az}$ erre irányuló erőfeszítések különösen az 1979-es első europarlamenti választás után öltöttek határozott formát.

Annak ellenére, hogy mind a mai napig nem született meg egy valamennyi érdekelt fél altal elfogadott variáns, 1996 közepén már egyetlen tagállam képviselöi sem kérdőjelezik meg az egységes európai választójogi rendszer kidolgozásának szủkségességét.

A tagállamok között azonban jelentősek a különbségek a választókerïletek nagyságát és számát, valamint a szavazás módját illetően. 1994 júniusáig az akkor még tizenkét országot tömörítő szervezet négy európai parlamenti választást ért meg. 1979-ben nendezték az elsőt (Görögországban 1981-ben - mivel később csatlakozott a Közösséghez), 1984-ben a másodikat (Portugáliában és Spanyolországban 1985-ös EGK belépésủk miatt 1987-ben), 1989-ben most már mind a tizenkét tagállamban egyidóben a harmadikat, s 1994 júniusában a negyediket.

Amint az 1. táblázatban látható, hét államban: Dániában, Franciaországban, Görögországban, Hollandiában, Luxemburgban, Portugáliában és Spanyolországban €gyetlen választókerülettel találkozunk. Belgium három, Írország négy, Olaszország öt, Nagy-Britannia Észak-Írországgal együtt nyolcvannégy kerületre oszlik. Németország egyedülálló módon választja európai képviselőit. Az Unió legtöbb mandátumával (99) rendelkező országa a nemzeti, a Bundestag választásokon alkalmazott eljárást követi. A listák közzététele tartományi, a szavazatok összeszámlálása és a helyek elosztása viszont nemzeti szinten történik. Az egységes európai választójogi rendszer kialakítása szempontjából azonban a problémát nem elsősorban a választókerületek száma jelenti. A tagországok ugyanis nagyságrendi besorolásuk szerint meghatározott számú képviselóvel nendelkeznek az Európai Parlamentben. A Franciaországban, Németországban és \$panyolországban meglévő választási küszöb sem tekinthető komoly. akadályozó tényezőnek. Az egyformaság nem jelent azonosságot elv alkalmazásával az eltérések kezelhetőek.

Az igazi problémát az Unió vizsgálódásunk szempontjából figyelembe vett és európai yálasztásokat már rendezett, tizenkét tagállama által alkalmazott eltérő választási formula es szavazási mód jelenti. Ezeken a területeken már nagyon nehezen feloldható elvi kuilönbségek gátolják az egységes rendszer és szabályozás létrehozását, kialakulását.

A vizsgált tizenkettöböl tizenegy esetben az arányossági formula valamilyen változatát, számítási módját alkalmazzák. Belgiumban, Dániában, Franciaországban, Hollandiában, Portugáliában és Spanyolországban a d'Hondt rendszer érvényesull. Németországban a Hare-Niemayer, Olaszországban a tiszta arányosság, Írországban az egyszerú átszámítás, Görögországban az enishimeni analogiki variáns az elfogadott. 


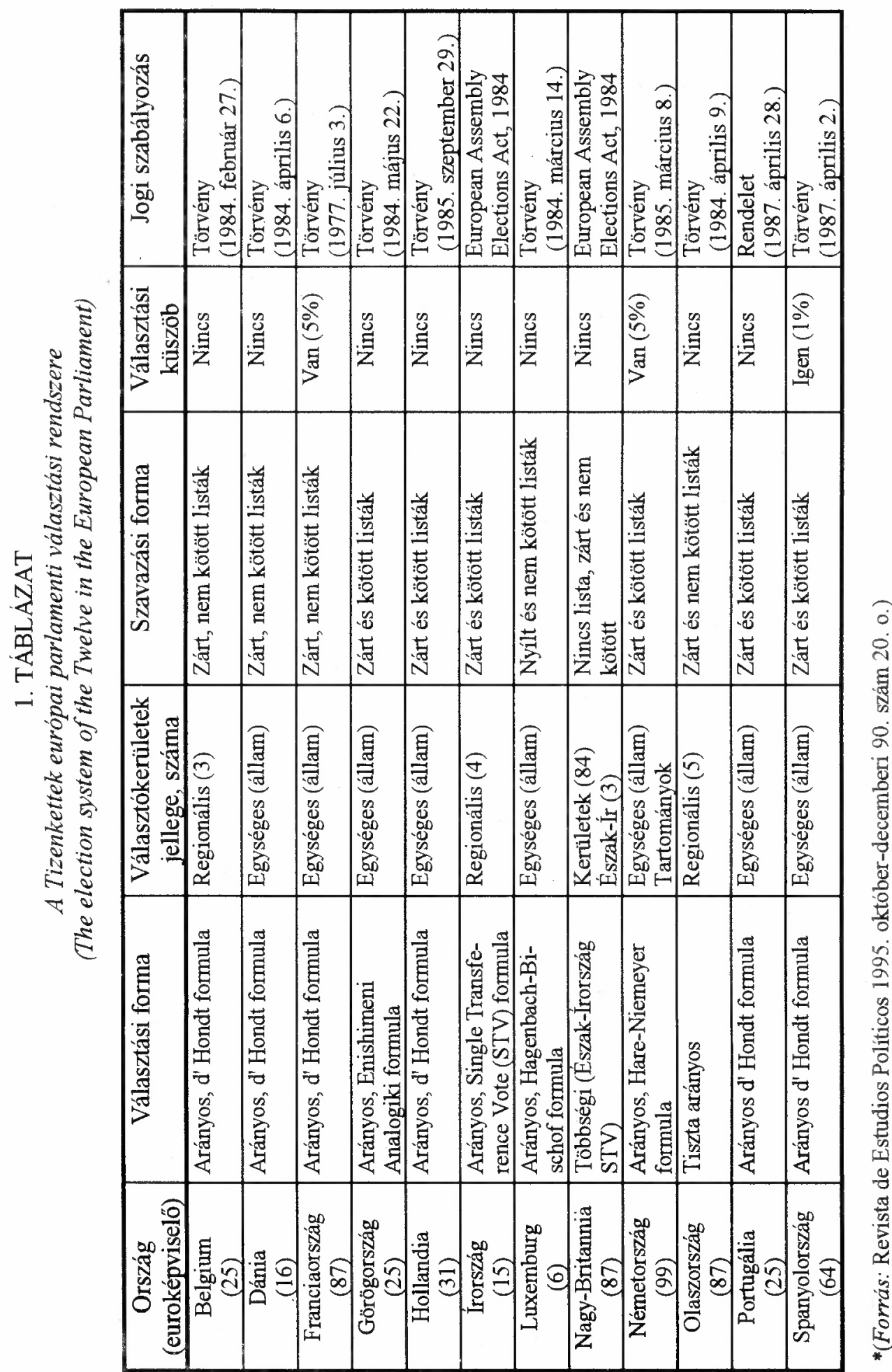


Egyedül Nagy-Britannia ragaszkodik a többségi elv alkalmazásához. S ez az arányos választási szabályok közös nevezőre hozása mellett egyik alapvetö akadálya az egységes választójogi rendszer kialakításának.

Hasonló problémát okoz a választási listák (zárt és kötött, nyílt és nem kötött, zárt és nem kötött) eltérỏ alkalmazása is.

A négy tényezö (választókerület száma és nagysága; választási küszöb léte vagy nem léte; arányos vagy többségi elv alkalmazása; zárt és nyitott, kötött és szabad listák) p.szenchúnti eltéró konstrukciója még az "egyformaság nem jelent azonosságot" mentóövének használata esetén sem kínálja a megoldás királyi útját. ehát, hogy a tizenöt tagúvá bővült Európai Unió nem volt képes egységes tójogi rendszer kidolgozására.

Az eddigi tapasztalatok azt bizonyítják, hogy nem csupán a kormányok, de az unióba tömörült országok állampolgárai sem azonosultak teljes mértékben a kialakítandó rendszer céljaivul. A nemzeti szuverenitás virtuális eszméjét nem csupán az államok, hanem az állammolgárok is nehezen adják fel. Annak ellenére, hogy a négy szabadság - az áru, a munkaerő, a szolgáltatások és a töke - Római Egyezményben biztosított akadálytalan mozgásának elve már rég a mindennapi élet gyakorlatává, természetes részévé vált Nyugat-Európában, a lakosság nem szivesen támogatja a döntési jogosultság további ónkorlátozását. Mindez megnyilvánul abban is, hogy az euroválasztásokat másodlagosnak tekintik a nemzeti megmérettetésekhez képest. Ezt a választási részvétel arányai hiven tükrözik, s e tényt az Európai Unió demokratikus deficitje egyik megnyilvánulásának is tekinthetjük. A 2. és a 3. táblázat adatai szerint a nemzeti és az euroválasztások részvételi arányai csak ott közelítenek egymáshoz, illetve esnek egybe, ahol mint Belgium, Görögország, Luxemburg és Olaszország esetében kötelező vagy kvázi kőtelezö a szavazás, vagy egyidőben, egyszerre rendezik a nemzeti és az euroválasztásokat. A negativ rekordot Nagy-Britannia tartja az 1979-es 32,3\%-os minimális és az 1994-es 36,4\%-os maximális euroválasztási részvétellel. 1994-ben Hollandia is közel került ehhez az alacsony küszöbhöz a maga 35,6\%-os arányával. A demokratikus deficitet "termelö" államok sorába tartozik Dánia, Franciaország és Portugália is. A kis északi ország euroválasztás részvételi átlaga csupán $49,8 \%$-ot tesz ki. Nem sokkal jobbak a francia $(54,7 \%)$ és a portugál adatok $(53,0 \%)$ sem.

A legmagasabb euroválasztási részvételi arányokat ezzel szemben Belgiumban $(91,2 \%)$, Luxemburgban $(88,4 \%)$ és Olaszországban $(81,2 \%)$ mérték.

Az Európai Unió demokratikus deficitjéröl írott elemzések (Boyce, B. 1993, Izikné Hedri G. 1994, Bulmer, S. 1995, Lodge, J. 1995) nagy teret szentelnek az intézmények "rendellenes" müködésének.

A klasszikus hatalommegosztás szabályai szerint a legmagasabb fórum a választott törvényhozás, az Európai Parlament. A Maastrichti Egyezmény szerint a testület négy alapvető funkciója: az Európai Unió Bizottsága tagjainak kinevezése, ellenőrzése; az EU költségvetés feletti kontroll, új tagok felvétele; a társulási megállapodások megkötésének a jóváhagyása; s az információkhoz való hozzájutás. Nem tartozik privilégiumai közé az unionális szabályozás, a közösségi törvényhozás. Azt az Európai Tanáccsal és a Miniszteri Tanáccsal megosztva gyakorolja.

Az Európai Parlament ugyanakkor nemzetek feletti, egyben föderális szervezet, amely az Unió tagországok állampolgárainak szavazatai alapján jön létre (Rubio Lara, $M . J$. 1993). 


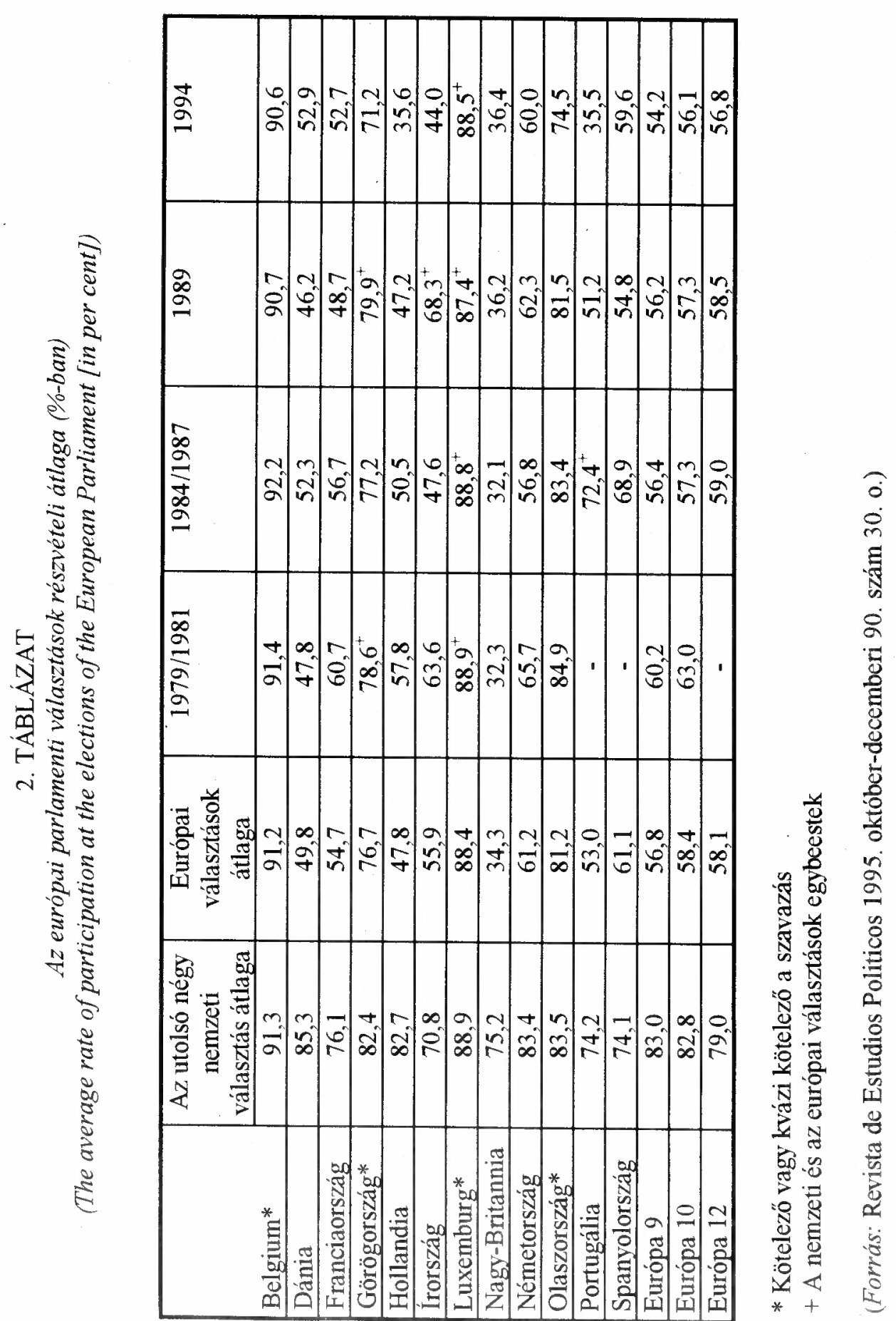




\section{TÁBLÁZAT}

Országok csoportositása az európai és a nemzeti választásokon való részvételi átlag alapján (Grouping of the countries by the average rate of participation at European and national elections)

\begin{tabular}{|c|c|c|c|c|}
\hline \multirow{4}{*}{$\begin{array}{c}\text { Európai } \\
\text { választások }\end{array}$} & & $\begin{array}{c}\text { Magas } \\
(85-100 \%)\end{array}$ & $\begin{array}{l}\text { Közepes } \\
(75-85 \%)\end{array}$ & $\begin{array}{l}\text { Alacsony } \\
(65-75 \%)\end{array}$ \\
\hline & $\begin{array}{c}\text { Magas } \\
(75-100 \%)\end{array}$ & $\begin{array}{c}\text { Belgium* } \\
\text { Luxemburg* } \\
\text { Olaszország* } \\
\text { Görögország* }\end{array}$ & & \\
\hline & $\begin{array}{c}\text { Közepes } \\
(50-75 \%)\end{array}$ & & $\begin{array}{c}\text { Európa } \\
\text { Franciaország } \\
\text { Spanyolország } \\
\text { Németország } \\
\end{array}$ & Írország \\
\hline & $\begin{array}{l}\text { Alacsony } \\
(0-50 \%)\end{array}$ & Dánia & $\begin{array}{c}\text { Hollandia } \\
\text { Nagy-Britannia }\end{array}$ & \\
\hline
\end{tabular}

*Kötelező vagy kvázi kötelezỏ a szavazás

Forrás: Revista de Estudios Politicos 1995. október-decemberi 90. szám 31. o.

Államok fölötti intézménynek fogható fel az Európai Unió Bizottsága is, amely a tényleges adminisztratív igazgatást, ügyintézést, a szerződések végrehajtásának ellenörzését biztosítja és látja el. Elnökét és tagjait azonban egyetértés alapján az Európai Parlament jóváhagyásával a tagállamok nevezik ki. Ebben az esetben is keverednek tehát a nemzetek felettiség (ellátandó funkció) és a kormányközi megegyezés (létrehozás) elemei. E szervezet is föderációs vonásokat hordoz, demokratikus legitimitása azonban erősen megkérdöjelezhetö.

A demokratikus deficit és a legitimitás ellentmondásos érvényesülésének paradigmatikus esetét testesíti meg a tagállamok állam-, vagy kormányföiböl álló Európai Tanács. E szervezet tipikus kormányközi intézménynek tekinthető, s a nemzeti szuverenitás igazi cerberusaként viselkedik. Mivel döntéseit egyetértésben, konszenzussal hozza, a föderációs rendszert nemzeti, nagy jóakarattal konföderációs mederbe tereli.

A Miniszteri Tanács szintén kormányközi szervezet. Azonban végrehajtó hatalmi funkciókkal is rendelkezik. Tagjait a napirenden szereplö témától függően a tagállamok jlletékes szakminiszterei - leggyakrabban a külügyminiszterek - alkotják. Annak ellenére, hogy a Miniszteri Tanács összetételét és létrehozását tekintve kormányközi szervezet (és ezért az Európai Unió szempontjából önálló nemzetközi jogi jogalany) csak az integráció és nem a tagállamok számára hozhat kötelezö döntéseket. Összetételét, felépitését, a szavazaterőt a tagországok lélekszáma határozza meg. ${ }^{3}$ Döntései elfogadásához kétharmados szavazattöbbség szükséges.

$\mathrm{Az}$ Európai Unió demokratikus müködésének fontos elemét képezi az EK Bírósága, továbbá az integráció alkotmánytervezetének vizsgálata során később részletezendó Gazdasági és Szociális, valamint a Regionális Bizottság is. Különösen ez utóbbi testület juthat jelentős szerephez az Unió demokratikus deficitjénak leküzdésében és legitimitása kialakításában (Barret $i$ Esteve, J. 1993, O'Leary, S.-Fernandez Martín, J. M. 1995), 
mellyel kapcsolatban szerzök jelentős csoportja - többek között Juliet Lodge is - a csalódások, a kiábrándulások, a vereségek katalógusáról elmélkednek (Lodge, J. 1995).

Kétségtelen tény, hogy már a Maastrichti Egyezmény aláíásának másnapján felbukkantak az 1996-1999 között teljeskörünek tételezett integrációval kapcsolatos jórészt megalapozottnak tekinthetó - europesszimista nézetek. Az Unió kiépítésének eredeti menetrendje mellett elkötelezett erők számára a gazdasági recesszió időszakában $a$ politikai integráció és az identitás jogi eszközökkel történö megerösitésének, az elöre menekülésnek $a z$ útjo látszot-látszik járhatćnak. $A z$ e téren felmutatható sikerekre nagy

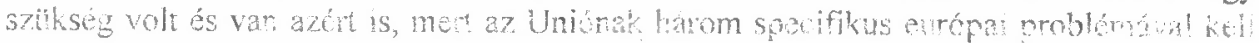

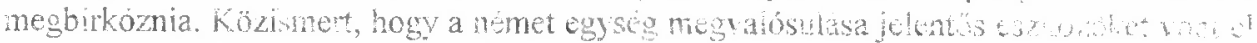
a közösségi költségvetésbọl. Nehéz helyzetbe keruilt ezáltal az ev ápai monetáris rendsz: s - amint már utaltunk rá - egyre hangosabban hallatjảk hangukat Kelet-Közép-Európa súlyos társadalmi feszültséggel terhes, gazdasági válsággal kủszködő új demokráciái.

$\mathrm{Az}$ európai integrációt azonban - ahogyan Armin von Bogdandy, a kérdés neves szakértője hangsúlyozza - egy "háromdimenziós átalakulási folyamatként írhatjuk le, amely egyszerre viseli magán a politikai, a jogi és a társadalmi megújulás bélyegét, s amely egy többközpontú, pluralista rendszer megjelenését eredményezi." (von Bogdandy, A. $1992: 19)$

$\mathrm{Az}$ európai integráció létrehozása mindenekelött a nemzetközi rend új formájának megszilárdulását jelenti. A nemzeti államokon túlmutató szisztéma nem hierarchikus jellegü, s nincs egy konkrét központban centralizált hatalma. A kialakult rendszer új típusú alkotmányt hoz létre, s radikalizálja a belső differenciálódási folyamatokat. "Ez a politika hatalmának elvesztéséhez, s a civil társadalom emancipációjához vezet... Mindezek következményeként az életvilág mélyreható átalakulása megy végbe" - hangsúlyozza a német tudós (von Bogdandy, A. $1992: 22$ ).

Ennek az életvilágnak az átfogó szabályozására, politikai, jogi kereteinek kialakítására csak egy új típusú közösségi alkotmány képes és alkalmas (Constantinesco, V. 1994, Arnold, Rainer 1994).

Az európai alapcharta kidolgozására 1996 közepéig két jelentös kisérlet történt. Az elsö közzétételére 1993 áprilisában került sor. Elöterjesztöjéröl, az Európai Parlament Alkotmányügyi Bizottságának akkori elnökéröl, a spanyol Marcelino Oreja Aguirréröl ${ }^{4}$ elnevezett tervezetet 1993. április 27-én vitatta meg a fent említett testület. A második változat 1994. február 10-én készült el. Ez már hasznosította az időközben lezajlott viták tapasztalatait, s konkrét szervezeti ajánlásokat is tett az Európai Unió demokratikus deficitjének csökkentésére. A tervezetekkel kapcsolatos diszkussziók foglalkoztak az egységes európai politikai rendszer megteremtésének kérdéseivel. Érintették a nemzeti szuverenitás és a szupranacionális alkotmány egymáshoz való viszonyát. Megoldásokat javasoltak az egységes európai választójogi rendszer kidolgozására, s vizsgálták az egyes országokon belül müködó regionális önkormányzatok helyét, szerepét és az európai állampolgárság jogi státuszát is.

A tervezetek az Európai Uniót sajátos jogközösségnek tekintik, amelynek meg kell felelnie a gazdasági egység, a társadalmi modell (a szabadságon és egyenlőségen alapuló jóléti állam), valamint a politikai berendezkedés (az állampolgárok akaratát képviselö demokratikus jogállam) elveinek, kritériumainak (de Carreras Serra, F. 1995).

A tervezetek koncepciója szerint a szuverenitás, azaz az adott területen élö népesség fölött gyakorolt döntési jogosultság még a tagállamokat illeti meg. Az alkotmányozó, azaz a létesitö hatalom, továbbá a demokratikus legitimitás letéteményesei és alanyi köre azonban már kettős természetüvé, duális szerkezetüvé vált. 
Az 1993-as dokumentum preambuluma egymás mellé állítja az államokat és az állampolgárokat. "Az államok és az Európai Parlament fogadják el az Európai Unió alkotmányát." - olvashatjuk (de Carreras Serra, F. 1993 : 15). Az Európai Parlamentet létesítő tényezők viszont nem mások, mint az Unió választásokon nemzeti keretek között résztvevơ és szavazó állampolgárok.

$\mathrm{Az}$ államok és az állampolgárok megváltozott viszonya nem csupán alkotmányjogi, hanem politikai problémákat is felvet. Az "alapító atyák" nagy gondban vannak a politikai modell meghatározásakor. Az Unió alkotmánytervezeteiben egymás mellett, egymást áthatva és egyszerre léteznek föderációs és konföderációs, államok fölötti és államok közötti, egységes intézményrendszerre és közös politikai térre utaló elemek, megoldások. A dokumentumok az Unió reális helyzetét tükrözik, amikor a kormányok kőzótti viszonyrendszer keretei közé helyezik a gazdasági, a pénzủgyi, a külügyi, a védelmi, a biztonsági, az igazságszolgáltatási és a belügyeket érintő kérdéseket. Az államközi szervek mellett azonban a szupranacionális hatalommegosztás jegyében megjelenik az Unió saját intézményrendszere is.

Az 1994. február 10-i dokumentumnál jóval koherensebb verziónak tekinthető 1993. aprilisi alkotmánytervezet három szervezettípust kodifikál. A 13. § (1) az Unió intézményeiről (Európai Parlament, Európai Tanács, Miniszterek Tanácsa, Európai Unió Bizottsága, Bíróság), a 13. § (2) a speciális intézményekröl (Európai Központi Bank, Számvevőszék, Gazdasági és Szociális, valamint Regionális Bizottság), a 13. § (3) egyéb, nem részletezett szervekről és ügynökségekról rendelkezik.

E testületek létrehozását, funkcióját, összetételét és tevékenységét nyomon kỏvetve kiderül, hogy mủkỏdésúkben az Európai Uniót jellemző két politikai filozófia - a föderalizmus és a konföderalizmus - elemei keverednek. Az alkotmányos építkezés így igen bonyolult, s az eddig alkalmazott, megszokott nemzeti sémáktól jelentós mértékben eltérơ utat és eljárást kỏvethet csupán. "Ugyanakkor mivel az alapvetô szerzódések nem tekinthetỏk alkotmánynak - hangsúlyozza Francésc de Carreras Serra - az Unió pedig allamnak, ezért mind a szabályozás módját, mind a politikai szervezeti formát tekintve olyan tertium genus konstrukcióval találkozunk, amelyet nehéz osztályba sorolni." (de Carreras Serra, F. $1995: 204)$

Tovább bonyolítja a helyzetet, hogy az 1993-as alkotmánytervezet preambuluma szerint az alapchartát létesítö alanyok: az állampolgárok és az államok "Az európai népek nevében..." hozzák döntéseiket. A jogi szempontból homályos és pontatlan kategória bevezetése azonban politikai realitásérzékről tanúskodik. Nyugat-Európa ugyanis - az Elbától Keletre eső régióhoz hasonlóan - különbözỏ tỏrténelmi-kulturális sajátosságokkal rendelkező népek és nemzetek nagy családjának tekinthetỏ. Az államhatárok nem mindig esnek egybe az etnikai határokkal, s az adott országon belül is különböző népcsoportok (flamand, vallon, baszk, gallego, katalán, breton, normand, skót, walesi stb.) élnek együtt és egymás mellett. A kulturális, politikai, vallási, nyelvi és gazdasági-szociális dimenziók mentén kimutatható, megnyilvánuló különbségek az Unió szemszögéböl nézve az egység és pluralizmus tudomásulvételét, intézményesítését, továbbá sajátos elegyítését jelentik.

Ennek kővetkeztében a demokratikus jogállam és a jóléti társadalom koncepcióját felvállaló alkotmánytervezet által vázolt államforma valóban a tertium genus kategóriájába tartozik. Nem írható le sem a parlamenti, sem az elnöki, sem a fơderációs, sem a konfóderációs modell képletével. Az Európai Parlamentet létesítő állampolgári részvétel, az Unió alkotmány, az alapjogok standardjának biztosítása, a nemzeti kompetenciák egy részẻnek közösségre történő átruházása parlamenti fỏderális rendszer irányába mutat. 
Az európai építmény elemeivel kapcsolatos konstruktív állami hozzájárulás formája, a különböző szerződések rendszere, a Tanács funkciója, az önálló alkotmányok léte a konföderációs modell sajátosságait erösíti. Igazat kell adnunk Francésc de Carreras Serrának, a Barcelonai Autonóm Egyetem alkotmányjog professzorának, aki az európai alkotmánytervezeteket elemzô munkájában az alábbi konklúzióra jut: "Végül is olyan intézményrendszerről van szó, amely nem adekvát sem a föderális, sem a konföderális megoldással, s különbözik a parlamenti és a prezidenciális formulától is. Mégis inkább hasonlít a föderációs és a parlamenti rendszerhez, mint a másik kettöhöz." (de Carreras Serra, F. $1995: 220$ )

$\mathrm{Az}$ államforma kérdésében megnyilvánuló politikai-jogi bizonytalanság jól nyomon követhetỏ az Unió állampolgárság státuszához kapcsolódó alapjogok esetében is.

A Maastrichti Egyezmény nyolcadik paragrafusa (Revista de Instituciones Europeas 1992. 1. 323-324.) mindössze öt alapjog felsorolására vállalkozik. A dokumentum a közösség valamennyi állampolgára számára:

- az Unió egész területén biztosítja a szabad helyváltoztatás és letelepedés jogát;

- bármely állam területén tartózkodjon is, a helyi hatalmi szervek, valamint az Európai Parlament esetében az aktív és a passziv választójogot;

- harmadik országok területén az Unió bármely tagállama diplomáciai és konzuli testületének jogvédelmét;

- az Európai Parlament elé benyújtandó petíció jogát, s az ombudsman elötti jogvédelmet.

E szabályozás érvényesül az említett alkotmánytervezetekben is. Az Európai Parlament azt ajánlja a tagállamoknak, hogy saját alaptörvényi normáikkal egészítsék ki e rövid felsorolást. Ezen túlmenően az Európai Unió, mint integrációs szervezet és nemzetközi jogalany csatlakozott az Emberi- és Politikai-, valamint a Gazdasági, Szociális és Kulturális Jogok 1966-os Nemzetközi Egyezményeihez. A jogok katalógusát folyamatosan bővítik a különböző egyedi ügyekben hozott, az angol precedens rendszerre emlékeztető közösségi bírósági határozatok is. ${ }^{5}$

Az európai állampolgár státusza tehát új politikai-jogi köteléket létesit az egyén és az Unió között.

E sajátos viszony alapjául azonban egy adott államhoz való tartozás szolgál. A föderációs jellegű kettős kapcsolat jogelméleti szempontból transzcendentális jelentőségünek bizonyul, mivel hagyományos kategóriákkal már nem írható le. Olyan új típusú állampolgárságot jelent, amely részben már el van választva a nemzeti hovatartozástól.

\section{Európai Unió és regionalizmus}

Nem kevés fejtörést okoz a közösség és az integráció számára a Nyugat-Európa jelentós térségeiben a belső jog szempontjából kielégítöen szabályozott regionalizmus konszenzusos rendezése (Olaszország, Belgium, Nagy-Britannia, Spanyolország, Franciaország, Németország). A probléma megoldását nehezíti az a körülmény, hogy a tagországok által a középszint számára biztosított jogkörök meglehetősen eklektikusak, s igen tarka képet mutat a földrajzi-területi és a közigazgatási beosztás is. 
Egyre inkább erösödik ugyanakkor az a felismerés, hogy a jövő Európája (Európai Uniója) a régiók Európája lesz, $\mathrm{s}$ a tévedés kockázata nélkül prognosztizálható az államok alatti, illetve az államok fölötti szintek növekvő szerepe. Azaz a közösségi integráció politikai-jogi döntéseinek végrehajtásában, alakitásában kulcsszerephez jutnak a területi és funkcionális középszint "közvetítő kormányzatai". Visszatér, újraéled és megerősődik tehát a civil társadalom (Pérez Díaz, V. 1987).

Az országhatárokon át- és túllépö régiók a fejlődés, a kooperáció és a nemzetköziesedés új irányát, lehetőségét és megoldásait jelentik. A kőzépszint pontos meghatározásáról és elnevezésérỏl azonban mind a mai napig viták folynak, s nem alakult még ki egységes értelmezés. Felfogásunkhoz a Siofra O'Leary és José María Fernandez Martin által adott meghatározás áll a legközzelebb. E szerint subállami entitáson "azon államok alá tartozó területi egységeket értjük, amelyeknek saját intézményes politikai képviseletük van, $\mathrm{s}$ amelyek az adott területen normatív kompetenciával és a központi szervektöl független végrehájtó szervekkel rendelkeznek" (O'Leary, S.-Fernandez Martin, J. M. 1995:300). Természetesen elismerjük más megközelítések jogosságát is. Ezért különösen használhatónak tartjuk az Európa Tanács Helyi és Regionális Közhatóságok Állandó Konferenciája által adott definiciót is (Locatelli, R. 1992).

A regionális szint szerepének és fontosságának felismerése nagy jelentöségủ az Európai Unió demokratikus deficitjének leküzdése, a szerves kapcsolódás és a területfejlesztés szempontjából is. A megalapozott politikai döntések azonban egységes értelmezési, számítási és nyilvántartási szisztémát igényelnek. Erre szolgál az Európai Unió területi statisztikai rendszere, a háromszintü NUTS (Nomenclature des unités territoríales statistiques) kialakítása is. A makro-, a mezo- és a mikrorégiók kritériumának világos meghatározása segít feloldani az európai középszint már jelzett tarkaságából eredö êrtelmezési nehézségeket és hozzájárul a pluralitás egységének megteremtéséhez (Pikler K. 1994).

A régiók Európájának koncepciója, a régiók és a regionális szabályozás kérdésköre már a Maastrichti Egyezmény és az alkotmánytervezetek megszövegezése elött felbukkant, s jelentős befolyást gyakorolt a közösség müködésére. Igaz ugyan, hogy a Régiók Bizottságát a Maastrichti Egyezmény hozta létre, a Gazdasági és Szociális Bizottság konzultációs szerveként. A szubszidiaritás elve alapján azonban már 1977-től múködött a középszintủ, a regionál is érdekek képviseletét ellátó Európai Régiók Közgyllilése, valamint az Európai Önkormányzatok és Régiók Tanácsa. Az EGK Bizottságának 1988. június 24-i határozata e szerveket beemelte az integráció intézményrendszerébe azáltal, hogy létrehozta az Európai Közösség Helyi és Regionális Intézményeinek Konzultációs Bizottságát. Az új fórumot tanácsadó szereppel ruházták fel, és a Gazdasági és Szociális Bizottság szakmai szerveként múködtették. ${ }^{6}$

1957 óta összeurópai jelleggel tevékenykedett a már említett Európa Tanács Helyi és Regionális Közhatóságok Állandó Konferenciája elnevezésủ szervezet is, amely a kontinens huszonegy tagállamának települései és területi önkormányzatai kőzött biztosította a közvetlen kapcsolatot. A konferencia különbözö rendezvényein mindig határozottan képviselte a kőzépszint érdekeit. Nem utolsósorban e szervezet eredményes tevékenységének is köszönhetö, hogy a Maastrichti Egyezményt aláíró államok a Régiók Bizottságának létrehozása mellett döntöttek. ${ }^{7}$

Nem maradt tétlen az Európai Régiók Közgyülése sem. Fokozta az EK testületeire gyakorolt nyomást, s 1990. december 6-i határozatában követelte a regionális szint intézményes részvételét az Európai Közösség döntési folyamatában. Olyan ơnálló alapszabállyal rendelkezỏ Regionális Konzultatív Tanács létrehozását javasolta, amelyben 
a földrész mind a százötvenkét autonóm közössége és régiója képviselve van. Az indítvány kezdetben nem örvendett nagy népszerúségnek. Az EK Bizottsága azonban támogatta a kezdeményezést. A pontot az i-re a Maastrichti Egyezmény tette fel.

A Szerződés 4., 198. A és 198. C paragrafusai önálló, ámde a Gazdasági és Szociális Bizottság konzultációs szerveként létrehozták a Régiók Bizottságát. Az Európai Parlament 1993. április 23-i határozata már az Unió demokratikus deficitje felszámolásának fontos tényezőjeként említi az új intézményt. A Gazdasági és Szociális Bizottság keretei között múködő szervezet ugyanakkor "közvetlenül a Bizottsághoz, vagy a Miniszterek Tanácsához fordulhat, $\mathrm{s}$ kifejtheti véleményét. Másfelól a sajátos regionális érdekek napirendre kerülése esetén rendelkezik a kezdeményezés jogával. Külön felkérés nélkül is eljuttathatja véleményét a Gazdasági és Szociális Bizottsághoz, amelynek azt továbbítania kell a Miniszterek Tanácsához, továbbá az Európai Unió Bizottságához." (Fontaine, Pascal-Malosse, H. 1992 : 49)

A Maastrichti Egyezményben intézményesített szervezet hatékony múködését egyes vélemények szerint akadályozza a Régiók Bizottsága összetételének vegyes jellege. Nemcsak az önkormányzati közösségek, hanem a helyi hatalmi szervek is delegálhatnak küldötteket a testületbe. Ebböl a szempontból az 1988-as Európai Közösség Helyi és Regionális Intézményeinek Konzultációs Bizottságához hasonlit. Az egybeesés azonban nem véletlen. Tükrözi és kifejezi a közösség tagállamainak eltérö politikai-közigazgatási szerkezetét, megoldásait. Ettől függetlenül a tagolt regionális középszint fontos tényezöje, nélkülözhetetlen láncszeme a régió, nemzeti állam, európai közösség alkotta hármas struktúrának.

A Régiók Bizottságának a Maastrichti Egyezmény 198. A paragrafusa alapján 189 tagja van. ${ }^{8}$ A testület - nevével ellentétben - nem csupán a regionális, hanem a helyi hatalmi testületek képviseletére is vállalkozik. S ez a vegyes jelleg - mint említettük összetételében, felépítésében is kifejezésre jut. 24 hely illeti meg Franciaországot, NagyBritanniát, Németországot és Olaszországot. 21 Spanyolországot, 12 Belgiumot, Görögországot, Hollandiát és Portugáliát, 9 Dániát és İrországot, 6 Luxemburgot. A felsorolt államok regionális és települési küldöttekkel képviseltetik magukat a Bizottságban. Görögország és Luxemburg esetében hiányzik a középszint. E két állam a lokális szervek képviselöit delegálja a testületbe.

A Régiók Bizottságának tagjait és helyetteseit az érintett államok javaslata alapján a Tanács nevezi ki négy évre. Mandátumuk megújítható. A Maastrichti Egyezmény 198. C paragrafusa alapján a Bizottság konzultációs és szakértői jellegü kompetenciája az Európai Szociális Alap, az oktatás, az ifjúság szakképzése, a gazdasági, társadalmi, szociális kohézió, a közegészségügy, a kultúra és más, esetenként eléje utalt kérdéskörre, ügyre terjed ki. A Bizottságban résztvevö képviselök és europolitikusok körében határozott törekvés tapasztalható a regionális és a lokális érdekképviselet intézményes szétválasztására. A kérdés megvitatása az 1996-os torinói kormányközi konferencia szervezeti reformokkal foglalkozó szekciójának egyik fontos feladatát képezi. Amiképpen az is, hogy megnyugtató válaszokat adjanak az integrációs alkotmánytervezetek négy felvetésére. Nevezetesen arra, hogy:

1. A közösségi szabályozás milyen mértékben csökkentse az állami és az önkormányzati kompetenciákat.

2. Az állami vagy az önkormányzati-regionális szintnek kell-e végrehajtania az Európai Unió rendelkezéseit. 
3. Az adott állam milyen eszközökkel rendelkezik arra nézve, hogy az autonóm közösségek végrehajtsák az Unió jogi rendelkezéseit.

4. Hogyan biztositható a regionális önkormányzatok részvétele a közösségi döntések elfogadásában.

A tagországok szintjén jelentkező megoldások - mint hangsúlyoztuk - meglehetősen eklektikusak. Az alkotmánytervezetek tiszteletben tartják a nemzeti államok szuverenitását, s a közösségi döntések végrehajtásának ellenórzését a belső jog szférájába utalják. Ennek Nyugat-Európában hármas garanciarendszere alakult ki. Múködik a kormányzati, a törvényhozási és a jogszolgáltatási biztosítékok rendszere. Ezzel párhuzamosan a Maastrichti Egyezményben az alảiró felek vállalták kompetenciájuk egy részének az Unió hatáskörébe való átadását, s érvényesül a belső mellett az Unió külső szubszidiaritásának elve is. E szerint: "Azokon a területeken, amelyek nem tartoznak kizárólagos illetékességi körébe, a Közösség a szubszidiaritás elvének megfelelöen csak akkor avatkozik be, ha a figyelembe vett célok a tagállamok által megfelelöen nem érhetök el, következésképpen terjedelmük vagy kihatásaik miatt közösségi szinten jobban kezelhetök." (Tratado de la Unión Europea. Revista de Instituciones Europeas, 1992. 1. 323.)

A szubszidiaritás azonban nem csupán a decentralizált - sőt nem elsősorban a decentralizált rendszerek politikai-jogi szerveződésének elvét, hanem sajátos társadalompolitikát is jelent. Másként fogalmazva: tásadalompolitikai szempontból a szubszidiaritás teória gyakorlati alkalmazása a felsöbb szervek beavatkozásának korlátozására irányul. Sajátos demokratikus rendezöelvet jelent, mivel azt az álláspontot képviseli, illetve testesíti meg, mely szerint a kompetenciákat az állampolgárokhoz legközelebb eső helyre kell telepíteni. Különbözö kormányzati szinteket és decentralizált politkai-közigazgatási struktúrát jelent, s alkalmazása a föderális vagy félfooderális dimenzió megerősödését szolgálja.

E kívánatos rendszer kialakítására egyes tagállamok már komoly erőfeszitéseket tettek, $\mathrm{s}$ az Unió követelményeknek megfelelően alkotmányreformot hajtottak végre. Ezzel erösítették a régiók részvételét a közösségi döntésekben. Ezt tette a német parlament az 1992. december 21-én elfogadott alaptörvényi módositással, amely a Bundesraton keresztül megteremtette az Unió döntésekben való önkormányzati szintü - a Landok bevonásával megvalósuló - részvétel lehetőségét.

A jelzett folyamatok még nem zárultak le. Az általános, unionális keretszabályozást finomabb jogtechnikáknak és politikai intézményeknek kell kiegészíteniük. Az azonban már világosan látható, hogy az egységes (nyugat-)európai alkotmánytervezetek megszületése és normarendszerének kiépülése a nemzetközi politikai viszonyok és jogfejlódés új irányainak az alapjait vetette meg. A jelzett tendenciák teljeskörủ kibontakozása és érvényesülése a harmadik évezred elejére várható. A magyar alkotmányozási folyamatnak és a kőzépszint fejlesztésével kapcsolatos elképzeléseknek számot kell vetniứk ezzel a realitással. 


\section{Jegyzetek}

1. Az 1992. február 7-én aláirt Maastrichti Egyezmény második cím G cikkelyének elsö bekezdése deklarálta az 1957-ben bevezetett és elfogadottá vált Európai Gazdasági Közösség megszünését, valamint az Európai Unió megteremtését.

2. Részletesen lásd: Alvarez Conde, E.-Arnaldo Alcubilla, E.: Criterios para la unificación electoral europea. Manuscript. Madrid, 1993; Bodony I.: Egységesülö Európa - egységesülő választójog. Magyar Közigazgatás, 1994. 5. 309-315. o.; valamint: Santamaría, J.-Reniú, J. M.-Cobos, V.: Los debates sobre el procedimiento electorel uniforme y las características diferenciales de las elecciones europeas. Revista de Estudios Políticos 1995. október-decemberi 90. 13-19. o. (A továbbiakban: REP).

3. Ausztria 4, Belgium 5, Dánia 3, Finnország 3, Franciaország 10, Görögország 5, Hollandia 5, Írország 3, Luxemburg 2, Nagy-Britannia 10, Németország 10 , Olaszország 10, Portugália 5, Spanyolország 8 és Svédország 4 szavazattal rendelkezik.

4. Marcelino Oreja Aguirre az európai egység eszméjének elkötelezett híve. A spanyol demokratikus átmenet egyik föszereplöje. 1976. július 3. és 1980. július 8. között Adolfo Suárez González több kormányában külügyminiszteri tisztséget viselt.

5. Részletesen lásd: Rallo Lombarte, A.: Los derechos de los ciudadanos europeos. Cuadernos Constituciona les 1994. 5. 67-89. o.

6. Részletesen lásd: Pérez González, M.: Algunas observaciones sobre el Comité de las Regiones y su función en el proceso de construcción de la Unión Europea. Revista de Instituciones Europeas 1994. 1. 31-59. o.

7. Részletesebben lásd: Locatelli, R.: Az Európai Tanács Helyi és Regionális Közhatóságok Állandó Konferenciája és a régiók. Magyar Közigazgatảs, 1992. 11. 653-659. o.

8. Az Európa Tanács 1993. december 10-11-én Brüsszelben tartott ülésén Ausztria (11), Finnország (9) és Svédország (11) csatlakozása esetén 31 fővel 220-ra növelte a Bizottság taglétszámát.

\section{Irodalom}

Alegre-Martinez, M.-A. (1993) Comunidades Autónomas y Derecho Comunitario Europeo. Manuscript. Madrid.

Alvarez Conde, E. (1993) Criterios para la unificación electoral europea. Manuscript. Madrid.

Arnold, Rainer (1995) Reflexiones sobre una futura Constitución europea. Cuadernos Constitucionales (Valencia) 8. 17-34. o.

Balázs I. (1995) A területi önkormányzatok feladat- és hatáskörének változásai Európában. Comitatus, 2. 12-22. o.

Barrat i Esteve, J. (1993) Los parlamentos nacionales y la legitimidad democrática de la Unión Europea. Manuscript. Madrid.

Bodony I. (1994) Egységesülő Európa - egységesülö választójog. Magyar Közigazgatás, 5. 309-315. o. 
Bogdandy, A. von (1992) Perfiles de la Europa integrada. Revista del Centro de Estudios Constitucionales. 15. 19-33. 0 .

Bogdandy, A. von (1994) Teoría Constitucional e integración europea. Manuscript. Madrid.

Boyce, B. (1993) The Democratic Deficit of the European Community. Parliamentary Affairs, 4. 458-478. o.

Carreras Serra, F. de (1993) Analisis del proyecto de Constitución europea. Manuscript. Madrid.

Carreras Serra, F. de (1995) Por una Constitución europea Revista de Estudios Políticos (REP) 90. 193-221. 0 .

Constantinesco, V. (1995) Hacia la emergencia de un Derecho constitucional europeo? Cuadernos Constitucionales (Valencia), 8. 5-17. 0.

Enyedi Gy. (1996) Magyarország regonális fejlődése 2010-ig. Comitatus, 2. 41-46. o.

Az Európai Közösségek Jogszabályainak Gyüjteménye 1. Alapintézmények. (1992) Unió Lap- és Könyvkiadó Kereskedelmi Kft., Budapest.

Az Európa Tanács Helyi és Regionális Közhatóságok Igazgató Bizottsága ülésének állásfoglalása a szubszidiaritás elvének érvényesüléséröl a tagországok önkormányzati rendszerében. (1994) Magyar Közigazgatás, 5. 257-267. és 6-7. 350-364. o.

Europa, un orden jurídico para un fin político. (1992) Fundación Cánovas del Castillo, Colección Veintiuno, Madrid.

Fontaine, Pascal-Malosse, H. (1992) Las Instituciones europeas. Ediciones RIALP, S. A. Madrid.

Horváth Gy. (1992) Az európai integráció regionalizálódása. (Nemzetközi kapcsolatok és regionális fejlödés). Magyar Közigazgatás, 10.600-609. 0.

Horváth Gy. (1995) A magyar regionális politika erős és gyenge pontjai. Comitatus, 6. 311. 0 .

Izikné Hedri G. (1994) Az Európai Unió intézményi és döntéshozatali rendszere. Közgazdasági Szemle, 7-8. 690-707. o.

Kádár B. (1996) Cui prodest Európai Unió? Magyar Tudomány, 2. 153-165. o.

Kurucsai Cs. (1996) Európai Régiók Gyülése. Comitatus, 1. 43-49. o.

Lodge, J. (1995) Legitimidad democrática y el Parlamento Europeo. REP, 90. 221-243. o.

Locatelli, R. (1992) Az Európa Tanács Helyi és Regionális Közhatóságok Állandó Konferenciája és a régiók. Magyar Közigazgatás, 11. 653-659. o.

O'Leary, S.-Fernandez Martin, J. M. (1995) Hacia la Europa de los regiones? El principio de subsidiariedad, la integración europea y el futuro de las entidades subestales. $R E P$, 90. 299-323. o.

Pérez Díaz, V. (1987) El retorno a la sociedad civil. Instituto de Estudios Económicos. Madrid.

Pérez González, M. (1994) Algunas observaciones sobre el Comité de las Regiones y su función en el proceso de Construcción de la Unión Europea. Revista de Instituciones Europeas. 1. 31-59. o.

Pikler K. (1994) Az Európai Unió statisztikai rendszerének magyarországi bevezetéséról. Comitatus, 8-9. 157-161. o.

Rallo Lombarte, A. (1994) Los derechos de los ciudadanos europeos. Cuadernos Constitucionales.(Valencia), 5. 67-89. o.

Rubio Lara, M. J. (1993) El sistema politico europeo. Manuscript. Madrid. 
Ruiz-Navarro Pinar, J. L. (1985) El parlamento europeo: sistemas electorales de los diez y alternativas de la futura ley electoral espańola. Revista de las Cortes Gnerales, 6. 340416. o.

Santamaría, J.-Reniú, J. M.-Cobos, V. (1995) Los debates sobre el procedimiento electoral uniforme y las caracteristicas diferenciales de las elecciones europeas. $R E P$, 90. 11-15. o.

Szilágyi I. (1993) Európaizálódás - Maastricht jegyében. In: A gazdasági-társadalmi rendszerváltás folyamata és tendenciái. VEAB, Veszprém, 127-135. o.

Szilágyi I. (1994) Egységesủlö Európa - alkotmányjogi dilemmák és távlatok. Comitatus, 8-9. 112-117. o.

Szilágyi I. (1996) Az Európai Unió és Magyarország esélyei. Comitatus, 3. 30-36. o.

Tratado de la Unión Europea. (1992) Revista de Instituciones Europeas, 1. 319-437. o.

\title{
EUROPEAN UNION: THE DEVELOPMENT OF THE CONSTITUTION AND REGIONALISM
}

\author{
ISTVÁN SZILÁGYI
}

\begin{abstract}
After the ratification of the Maastrocht Treaty, the process of the European intergartion accelerated in political and legal sense. In 1995 Austria, Finland and Sweden joined the "Twelve". A further expansion of the Union and deepening the co-operation among the member states is expected.

The censequences are serious organisational, political and legal-constitutional problems and conflicts and many question emerge: Will the democratic deficit of the European Union cease, can it be ceased? Will a single electoral system be created? Will the normative .... regulation of the Union come into being and what will it contain? How will the relationship between the national and supranational institutions develop? How will the principle of subsidiarity be asserted? How will the decision-making mechanism be modified? Will the fhe future single European House be organised in the form of a federation or confederation, in parliamentary or presidential system? What will the future system of regional regulation and support look like?

The members states are coming to realise that the future Europe will be a Europe of the regions, and we cannot be wrong whwn forecasting the growing importance of the levels below and above the national states. This means that in the implementation and formation of the political and legal decisions fo the community integration, the "intermediate governments" of the regional and functiomal medium level will have a dominant role.
\end{abstract}

